\title{
Монгол-Японы эрчим хүчний харилцаа
}

Т.Амгалан, ОУСХ, Эма

Япон улс нь аж үйлдвэр, технологийн хувьд дэлхийд тэргүүлэх өндөр хөгжилтэй, түүнийгээ дагаад эрчим хүчний хэрэглээ өндөртэй улс хэдий ч байгалийн баялагийн хувьд хязгаарлагдмал нөөцтэй учир дотоодын эрчим хүчний хэрэгцээний ердөө 16 хувийг өөрсдийн хүчээр хангаж, үлдсэн 84 хувийг импортын түүхий эдээр хангадаг улс юм. Япон улс нь газрын тосны импортоор дэлхийн хэмжээнд гуравдугаарт, шингэрүүлсэн байгалийн хийн импортоор нэгдүгээрт, нүүрсний импортоор хоёрдугаарт ордог. Иймээс Японы компаниуд хилийн чанад дахь газрын тос, байгалийн хий олборлох төслүүдэд идэвхитэй оролцохын зэрэгцээ дэлхийн хэмжээнд хэрэгжиж буй эрчим хүчний төслүүдэд инженерийн, барилга байгууламж болон санхүҮ, төслийн менежментийн үйлчилгээг үзүүлдэг юм. Мөн Япон нь эрчим хүчний салбарын тоног төхөөрөмжийн томоохон экспортлогч орон бөгөөд японы компаниуд эрчим хүчний аюулгүй байдлыг хангах, нүүрстөрөгчийн давхар ислийн ялгарлыг бууруулах зорилго бүхий төсөл, хөтөлбөрүүдийг Засгийн Газрын тусламжтайгаар тогтмол хэрэгжүүлж ирсэн байна.

Газар хөдлөлтийн өмнөх жил буюу 2010 оны Японы эрчим хүчний хэрэглээг эх ҮҮсвэрээр нь үзвэл:

- Газрын тос $42 \%$

- HYypc 22\%

- Байгалийн хий $18 \%$

- Цөмийн эрчим хүч $13 \%$

- Усны эрчим хүч $3 \%$

- Бусад сэргээгдэх эрчим хүч $1 \%$

Газрын тос: Дотоодын газрын тосны нөөцийн хувьд маш хязгаарлагдмал бөгөөд 2007 онд 58 сая.баррель байсан бол 2012 оны 1-дүгээр сарын байдлаар 44 сая.баррель болж буурсан байна. Япон улс 2011 онд өдөрт 4.5 сая баррель газрын тос ашиглаж байсан нь 2010 онтой харьцуулахад 30.000 барреллиэр нэмэгдсэн үзүүлэлт юм.

Газрын тосныл импортыг улсуудаар нь үзвэл (2011):

- Саудын Араб 33\% 
- Кувейт 7\%

- Катар $10 \%$

- АНЭмират $23 \%$

- Иран 9\%

- OXУ $4 \%$

- Бусад улсуудаас $14 \%$

Байгалийн хий: Япон улсын байгалийн хийн тогтоогдсон нөөц нь 2007 онд 1.4 триллион метр ${ }^{3}$ байсан бол 2012 оны нэгдүгээр сарын байдлаар 738 тэрбум метр 3 болж буурсан байна. Хэрэглээний хувьд 2010 онд нийт 174 тэрбум метр 3 байгалийн хий ашиглажээ.

\section{Байгалийн хийн импортыл улсуудаар нь узвэл (2011):}

- OXY 9\%

- Оман $5 \%$

- Катар $15 \%$

- АНЭмират 7\%

- Австрали $18 \%$

- Бруней 8\%

- Индонези $12 \%$

- Малайз 19\%

- Бусад улсуудаас 7\%

Цөмийн эрчим хүч: Фүкүшимагийн ослоос өмнө Япон нь цөмийн эрчим хүч үйлдвэрлэлтээр АНУ, Францын дараа дэлхийд гуравдугаарт жагсаж байсан ч цөмийн эрчим хүч үйлдвэрлэлийн чадавхийн үзүүлэлт нь газар хөдлөлтөөс үүдэлтэй гэмтэл, стандартын дагуу шалгалт хийх зорилгоор тоног төхөөрөмжийг 13 сар тутамд унтраадагтай холбоотойгоор суларсан бөгөөд сүүлийн реакторыг 2012 оны 5 сард унтрааснаар 2010 онд 68 хувьтай байсан цөмийн эрчим хүч ашиглалтын зэрэг нь 2011 онд 38 хувь болж буурсан байна.

Нуүрс: Нүүрсний хувьд Япон улс нь зуун хувь импортоос хамаардаг бөгөөд нүүрс нь бусад эрчим хүчний их үүсвэртэй харьцуулахад удаан хугацаанд ашиглагдаж байгаа, дэлхий даяар өргөн ашиглагддаг, бусад түлштэй харьцуулахад нийлүүлэлт тогтвортой зэргээс хамааран эдийн засгийн хувьд тэргүүлэх ач холбогдолтой хэвээр байна. Түүнээс гадна Японд нүүрсийг ган хайлуулах салбарт өргөнөөр хэрэглэдэг бөгөөд ган 
үйлдвэрлэлийн хувьд өнөөдөр Японы Төмөр болон гангийн холбоонд бүртгэлтэй 57 ган үйлдвэрлэдэгч компани байна.

\section{Нуурсний импортыг улсуудаар нь үзвэл (2011):}

- Австрали $61 \%$

- Индонези $19 \%$

- Хятад 7\%

- Канад 5\%

- OXY $5 \%$

- Вьетнам $1 \%$

- Бусад улсуудаас $2 \%$

\section{1 оны газар хөдлөлтийн дараа Японы эрчим хүчний бодлогод гарсан өөрчилт:}

Дээр дурсдсанчилан Японы эрчим хүчний салбар түүхийн эдийн импортоос ихээхэн хамааралтай байдаг учир Япон улс нь эрчим хүчний стратегийн төлөвлөгөөгөө I) Эрчим хүчний аюулгүй байдлыг хангах II) Хүрээлэн буй орчныг хамгаалах III) Yp ашигтай ханган нийлүүлэлт хэмээх гурван үндсэн чиглэлийг баримтлан боловсруулсан байна. Цөмийн эрчим хүч нь дэлхийн зах зээл дээрхи газрын тос, байгалийн хий үнэтэй харьцуулахад илүү хямд байсан учир газар хөдлөлтөөс өмнө Японы эрчим хүчний салбарын гол тулгуур болж ирсэн бөгөөд энэ салбарт Засгийн газар болон аж үйлдвэрийн салбарыхан нягт хамтран ажиллаж байсан юм. Түүнээс гадна хүлэмжийн хийн ялгарлыг багасгах, уур амьсгалын өөрчлөлтөд эерэгээр нөлөөлөх гэсэн зорилтууд нь цөмийн эрчим хүчний ач холбогдолыг улам бүр нэмэгдүүлж байсан тул Японы Засгийн газраас баталсан эрчим хүчний төлөвлөгөөнд цөмийн эрчим хүчний үйлдвэрлэлтийг 2030 он гэхэд 50 хувь болгон өсгөх зорилго тусгагдсан байлаа.

Харин газар хөдлөлтийн дараа цөмийн эрчим хүч үйлдвэрлэх явдлыг зогсоосон нь байгалийн хий, газрын тосны импортыг огцом нэмэгдэхэд хүргэсэн бөгөөд 2011 онд байгалийн хийн хэрэглээ 20 хувиар, газрын тосны хэрэглээ 85 хувиар нэмэгдсэн байна. Иймээс Японы засгийн газрын өмнө эрчим хүчний боломжит өөр эх үүсвэр эрэлхийлэх шаардлага тулгарсан бөгөөд энэ тохиолдолд нүүрсний шинэ ханган нийлүүлэгч, нар, салхи гэх зэрэг сэргээгдэх эрчим хүчний асуудлууд ихээхэн хөндөгдөх болсон юм. Харин цөмийн цахилгаан станцуудыг дахин ажиллуулах асуудал нь олон нийтийн зүгээс ширүүн эсэргүүцэлтэй тулгарсан ба үүний тод илрэл нь 2011 оны 8 сард “Асахи шинбүн” 
сонины зүгээс 2000 хүний дунд явуулсан санал асуулгын үр дүн юм. Судалгаанд оролцогчдын 85 хувь нь сэргээгдэх эрчим хүчийг илүүд үзнэ гэж хариулсан байна. Түүнээс гадна Япон засгийн газраас цөмийн эрчим хүч нь хямд өртөгтэй гэсэн ойлголтыг арилгах зорилгоор цөмийн эрчим хүчний үнийг дахин тооцоолох ажлын хэсэг байгуулснаар судалгааны дүнд байгалийн гамшиг, цөмийн хортой хаягдалыг булшлах зэрэг зардлуудыг тооцоолон үзсэн ба цөмийн эрчим хүчний үнэ нь нарнаас эрчим хүч гарган авахтай адил зардалтай болох нь тогтоогдсон байна.

Гэхдээ өнөөгийн байдлаар сэргээгдэх эрчим хүч Японы нийт эрчим хүч үйлдвэрлэлийн дөнгөж 1 хувийг эзэлж байгаa, мөн ойрын хугацаанд сэргээгдэх эрчим хүчийг цөмийн эрчим хүчийг орлох хэмжээгээр үйлдвэрлэх боломжгүй учир Японы эрчим хүчний ойрын ирээдүйн стратегид цөмийн эрчим хүч, нүүрс, ураны импорт чухал байр суурь эзэлсээр байх нь тодорхой юм.

\section{$\underline{\text { Монгол }}$}

Монгол улсын хувьд эрчим хүчний хэрэглээ харьцангуй бага ч ашигт малтмалын хувьд асар их нөөцтэй юм. Үүнд алт, зэс, нүүрс, төмрийн хүдэр, мөнгө, жонш, уран гээд 80 орчим төрлийн ашигт малтмалын 1170 орд, 7600 гаруй илэрц байгаа нь тогтоогдоод байна. Монголын нутаг дахь нийт нүүрсний нөөцийн хэмжээ нь 160 орчим тэрбум тонн бөгөөд, эдгээр нүүрсний ордод мөн 70 тэрбум тонн метан хийн нөөц бий гэсэн судалгааны дүн гарсан ба Монголын нүүрсний хамгийн том орд нь 6.4 тэрбум тонн нүүрсний нөөцтэй Таван толгойн орд юм. Төмрийн хүдрийн хувьд 2007 оноос гаднаас ихээхэн хөрөнгө оруулалт орж ирэх болсоноор олборлорт, экспорт нь эрс нэмэгдэж 2011 оны байдлаар нийтдээ 5 сая тонн орчим төмрийн хүдэр экспортолсон байна. Харин газрын тосны хувьд монголын нийт нутаг дэвсгэр дээр 25 талбайд газрын тосны хайгуул, олборлолт хийж байгаа бөгөөд 2011 онд 3 сая орчим баррель газрын тос экспортолсон бол, энэ оны эхний 5 сарын байдлаар 1.2 сая орчим баррель газрын тос экспортолсон тооцоо байна. Мөн Монголын нутагт дэвсгэрт 62 мянган тонн ураны нөөц бий гэсэн тооцоо гарсан байна.

\section{Монгольен экспортын бутээгдхуунуудийг төрлөөр нь авч үзвэл 2012-07-15:}

- НүYрс $47.3 \%$

- Зэсийн баяжмал $18.9 \%$

- Төмрийн хүдэр $11.3 \%$ 
- Боловсруулаагүй газрын тос $6.7 \%$

- Цайрын хүдэр, баяжмал $2.4 \%$

- Хайлуур жоншны хүдэр, баяжмал $2.1 \%$

- Боловсруулаагүй буюу хагас боловсруулсан алт $1.9 \%$

- Молибдений хүдэр ба баяжмал $0.8 \%$

- Экспортын бусад бүтээгдхүүнүүд 8.6\%-ийг тус тус эзэлж байна.

Нийт экспортын 91.4 хувийг уул уурхайн гаралтай бүтээгдхүүн эзэлж байгаагаас үзэхэд бидний анхаарлаа хандуулах ёстой нэг зүйл нь эдгээр ашигт малтмалууд бүгд боловсруулагдаагүй буюу хагас боловсруулсан хэлбэрээр экспортлогдож байгаа явдал юм.

\section{Монгол-Япон эрчим хучний салбарын харилцаа:}

Дээрхи мэдээллээс үзэхэд манай хоёр улсын хувьд Япон нь худалдан авагчийн, харин Монгол улс нийлүүлэгчийн байранд байгаа, мөн Японы газрын тос, нүүрс, байгалийн хийн нийлүүлэгч улсуудын тоонд Монгол улс багтаагүй нь анзаарагдаж байна. Тиймээс манай хоёр улсын хувьд эрчим хүчний салбарын харилцаа бол харьцангуй шинэ ойлголт бөгөөд доор дурдах гэж буй эрчим хүчний салбарын харилцаа бол гол төлөв төрийн тэргүүн, засгийн газрын тэргүүн, сайд нарын түвшинд санал солилцох, мэдэгдэл гаргах, гэрээ хэлэлцээр байгуулах зэргээр өрнөж буйг дурдах нь зүйтэй юм.

2007 онд МУ-ын Ерөнхийлөгч Н.Энхбаяр, Япон улсын Ерөнхий сайд Шинзо Абэ нарын гарын үсэг зурсан “Монгол-Японы хамтын ажиллагааны 10 жилийн үндсэн хөтөлбөр"-т уул уурхайн салбарт хамтран ажиллах тухай тусгаж, хоёр улсын хамтын ажиллагааны үр дүнд Монголын байгалийн баялагийг эзэмшихэд оролцох сонирхолтой компаниудыг хамарсан зүй зохистой механизм бий болгож, Монголын ашигт малтмалыг иж бүрэн эзэмших асуудлыг авч хэлэлцэхээр тусгасан юм. 2010 оны 8 сард Монголд айлчилсан Японы ГХ-ийн сайд Окада Кацуя Таван толгойн орд, ураны салбарт японы хувийн хэвшлийхэн оролцох сонирхолтой байгааг илэрхийлсэн байна. Үүний дараа 2010 оны 11 сард Монгол улсын Ерөнхийлөгч Ц.Элбэгдорж Япон улсад айлчилсан айлчлалынхаа үеэр Япон улсын Ерөнхий сайд Н.Кантай хэлэлцээ хийж, хэлэлцээнийхээ үр дүнгээр хамтарсан мэдэгдэл гаргасан юм. Уг мэдэгдэлд “Иж бүрэн түншлэл”-ийн зарчимд тулгуурлан “Стратегийн түншлэл” байгуулах шинэ зорилт дэвшүүлсэн бөгөөд энэ зорилгоор хамтран ажиллахад идэвхижүүлэх шаардлагатай салбаруудыг дурдсаны 
дотор эдийн засаг, түүний дотор уул уурхайг онцгойлон дурдсан юм. Монголын талаас нүүрс, зэс, уран, ховор метал, газрын ховор элемент зэрэг эрдэс баялагаа ашиглахдаа тэргүүний технологи, туршлага бүхий Япон улстай хамтран ажиллах сонирхлоо илэрхийлсэн бол Японы талаас хөрөнгө оруулалтын орчноо улам боловсронгуй болгох арга хэмжээ авна гэж итгэж байгаагаа илэрхийлсэн юм. 2012 оны 3-р сард МУ-ын Ерөнхий сайд С.Батболд Япон улсад айлчлах үеэрээ Япон улсыг нь гуравдагч хөрш хэмээн зарлаж Япон улстай стратегийн түншлэлийг хөгжүүлэн, Япон улстай эдийн засгийн харилцаагаа хөгжүүлэн шинэ шатанд гаргаж, эрчим хүчний салбарт Японы дэвшилтэт бөгөөд байгаль орчинд ээлтэй технологийг нэвтрүүлэн ашиглах, японы хөрөнгө оруулалтыг нэмэгдүүлэх, Япон улсын тусламжтайгаар боловсон хүчин бэлтгэх, цаашилбал эрчим хүчний олборлолттой холбоотойгоор автозам, төмөрзам, харилцаа холбоо болон эрчим хүчний сүлжээг бий болгох сонирхлоо илэрхийлсэн юм. Нүүрсний салбарт Японы “Мицуй” компани “Эрдэнэс-Тавантолгой”-той Санамж бичигт гарын үсэг зурж, нүүрс худалдан авахаар болсон юм. Газрын тосны салбарт Японы "Тоёо инженеринг", "Марубени" корпораци болон "Монголсэкию" компани хамтран газрын тос боловсруулах үйлдвэрийг барьж байгуулахаар төслийн "Үндсэн гэрээ"-нд гарын үсэг зураад байгаа бөгөөд уг үйлдвэр 2014 он гэхэд бүрэн ашиглалтанд орох юм. Зэс, ураны салбарт Японы “Марубени” корпораци хөрөнгө оруулах сонирхлоо илэрхийлээд байгаа бөгөөд техник, тоног төхөөрөмж нийлүүлэх асуудалд гол анхаарлаа хандуулан уурхайн тоног төхөөрөмж, машин механизм нийлүүлэх хамтарсан компани байгуулаад байгаа юм.

Эрчим хүчний салбарт Монгол-Японы хооронд хэлэлцэгдэж буй бас нэгэн асуудал бол сэргээгдэх эрчим хүч бөгөөд Монголын говийн салхинаас жилдээ 682 тэрбумм кВт.цаг цахилгаан үйлдвэрлэх боломжтой гэсэн тооцоо байдаг юм. Үүнтэй холбоотойгоор Японы Софт банк, Өмнөд Солонгосын КЕПКО, Монголын Ньюком компаниуд хамтран сэргээгдэх эрчим хүчний “Азийн эрчмийн супер сүлжээ” төслийг санаачилж, хэрэгжүүлэхээр судалгаагаа эхлүүлээд байна.

Эцэст нь дурдахад манай хоёр улс хууль эрхзүйн орчоо зөв бүрдүүлж, өндөр технологид тулгуурласан, хүрээлэн буй орчноо хамгаалахад чиглэгдсэн стратеги боловсруулан, харилцан ашигтай харилцаа цогцлоож чадвал эрчим хүчний салбар нь манай хоёр улсын харилцаан дахь нэгэн гол салбар болох нь тодорхой харагдаж байна.

Ашигласан материал: 
1. U.S. Energy Information Administration: "Country Analyses Briefs - Japan"

2. Jane Nakano, David Pumphrey: "Japanese Energy Policy One Year Later"

3. www.world-nuclear.org: "Nuclear power in Japan"

4. Andrew Dewit: "The earthquake in Japanese Energy Policy"

5. Japanese Statistical Handbook 2011-Chapter 7-Energy

6. Монголын Үндэсний Статистикийн Хороо албан ёсны вэб хуудас

7. “Стратегийн түншлэл” байгуулахад чиглэсэн Монгол, Японы хамтарсан мэдэгдэл

8. Япон улсын Гадаад хэргийн сайд Окада Кацүяагийн Монгол улсад хийсэн албан ёсны айлчлалын мэдээ

9. Монгол Улсын Ерөнхий сайд С.Батболдын Японы улсын Ерөнхий сайд Ё.Нодатай албан ёсны хэлэлцээ хийсэн тухай мэдээ.

10. С.Энхбат: “Монгол улсад цөмийн эрчим хүчийг ашиглах нь”

11. Монгол, Японы Засгийн газрын хэвлэлийн хамтарсан мэдэгдэл 